Bangladesh J. Plant Taxon. 21(2): 167-173, 2014 (December)

(C) 2014 Bangladesh Association of Plant Taxonomists

\title{
A NEW SPECIES OF HYDROCOTYLE L. (ARALIACEAE) FROM INDIA
}

\author{
S. Karuppusamy, M. Ajmal Ali ${ }^{1}$, K. M. Rajasekaran, Joongku LeE ${ }^{2}$, Soo-Yong Kim², \\ Arun K. Pandey ${ }^{3}$ and Fahad M. A. Al-Hemaid ${ }^{1}$ \\ Department of Botany, The Madura College, Madurai-625011, Tamil Nadu, India
}

Keywords: Hydrocotyle kollimalayensis; India; ITS; New species; nrDNA.

\begin{abstract}
Hydrocotyle kollimalayensis, a new species is described and illustrated from Kolli hills of South Eastern Ghats, Tamil Nadu, India. The new species is morphologically closer to $H$. sibthorpioides, but differs from the latter by its filiform stem, glabrous peduncle, shorter petiole and narrower flowers. The most prominent features of the new species Hydrocotyle kollimalayensis are: stem filiform with silky setaceous hairs; leaves sparsely hirsute above and dense below, 5-lobed; flowers 6-12 per inflorescence with glabrous peduncle; and fruits ellipsoidal with 3 obscure ribs. A key to distinguish the new species from other Hydrocotyle species of Tamil Nadu, India is provided. We also inferred the relationship of $H$. kollimalayensis with allied species using molecular phylogenetic analyses based on nrDNA ITS sequence data.
\end{abstract}

\section{Introduction}

Hydrocotyle L. (Araliaceae) comprises some 130 species worldwide (Du and Ren, 2010). Most of them inhabit marshy, moist shady and understory environments in tropical and subtropical forests. The genus Hydrocotyle possess small, bisexual regular flowers on pedunculate, axillary or terminal umbel, and the plant body is covered with hispid hairs (Hiroe, 1979; Pimenov and Leonov, 1993). Karthikeyan et al. (2009) recognized eight taxa of Hydrocotyle from India i.e. Hydrocotyle conferta Wight, H. hookeri (C.B. Clarke) Craib, H. javanica var. hookeri C.B. Clarke, $H$. nepalensis Hook., $H$. podantha Molk., $H$. ramiflora Maxim., $H$. siamica Craib and $H$. sibthorpioides Lam.

While the first author was carrying out a survey of plant diversity across Eastern Ghats region of India in 2009, he came across some populations (about 90 patches in about 2 sq. km) of Hydrocotyle in Solakkadu area of Kolli hills with novel characters in the leaves, inflorescence, flowers and fruits, which were different from the other known species of Hydrocotyle. This led us to carry out detailed morphological and molecular phylogenetic studies for its proper identity and comparison with its allied species. The results revealed that these specimens belong to a hitherto undescribed species that is morphologically allied to $H$. sibthorpioides, $H$. conferta and $H$. javanica. Based on extensive morphological and molecular studies, we herein describe and illustrate the species as a new entity, Hydrocotyle kollimalayensis S. Karup. \& A. Ali.

\section{Materials and Methods}

The morphological characters of Hydrocotyle kollimalayensis were critically studied, and further compared with related taxonomic literature (Clarke, 1879; Gamble, 1935; Mathias, 1936; Hiroe, 1979; Matthew, 1983, 1996; Mukherjee and Constance, 1993; Pullaiah et al., 2007), and herbarium specimens housed at Botanical Survey of India, Central National Herbarium, Howrah

\footnotetext{
${ }^{1}$ Department of Botany and Microbiology, College of Science, King Saud University, Riyadh-11451, Saudi Arabia. Corresponding author. Email: majmalali@ rediffmail.com

${ }^{2}$ International Biological Material Research Center, Korea Research Institute of Bioscience and Biotechnology, Daejeon-305806, South Korea

${ }^{3}$ Department of Botany, University of Delhi, Delhi-110007, India
} 
(CAL), Madras Herbarium, Southern Regional Center, Coimbatore (MH), Sikkim Himalayan Regional Center, Gangtok (BSHC), Arunachal Pradesh Regional Center, Itanagar (ARUN), Eastern Regional Center, Shillong (ASSAM), and Northern Regional Center, Dehradun (DD).

For molecular study, the taxa along with sources and GenBank accession numbers are provided in Appendix 1. Leaf sample of $H$. kollimalayensis, $H$. sibthorpioides, $H$. javanica and $H$. conferta were collected during various plant exploration trips in Tamil Nadu, India. All the voucher specimens including the holotype of $H$. kollimalayensis have been deposited at the Madras Herbarium (MH). The leaf materials were fixed in silica gel. Total DNA was extracted using the DNeasy Plant Mini Kit (Qiagen, Valencia, CA, USA). The nuclear ribosomal DNA (nrDNA) Internal Transcribed Spacer (ITS) region was amplified using the primers ITS1 and ITS4 (White et al., 1990). PCR products were purified using SolGent PCR Purification Kit-Ultra (Solgent, Daejeon, South Korea) and sequenced employing the primers ITS1 and ITS4 in $10 \mu \mathrm{l}$ reactions including $2 \mu \mathrm{l}$ BigDye, $1 \mu \mathrm{l}$ primers $(20 \mathrm{pM})$ and template DNA, and deionized water to reach the final reaction volume. Cycle sequencing used 25 cycles of $96^{\circ} \mathrm{C}$ for $10 \mathrm{~s}, 50^{\circ} \mathrm{C}$ for $5 \mathrm{~s}$, and $60^{\circ} \mathrm{C}$ for $4 \mathrm{~min}$. Sequencing products were visualized on an ABI Prism 377 automated DNA sequencer. Each sample was sequenced in both the sense and anti-sense direction. The sequences were analyzed by the ABI Sequence Navigator software (Perkin-Elmer/Applied Biosystems). Nucleotide sequences of both the DNA strands were obtained and compared with the forward and reverse sequence to ensure the accuracy.

The nrDNA ITS sequences of Hydrocotyle species available in the GenBank were retrieved (Appendix 1) for comparison and phylogenetic analysis. The GenBank retrieved sequence of Centella asiatica (L.) Urban was selected as outgroup in the analysis as a follow up of Choi and Park (2012). Sequences were aligned using Clustal X (Thompson et al., 1997). The aligned sequence was subsequently adjusted manually using BioEdit (Hall, 1999). All sequences generated in the present study were deposited in GenBank. We constructed phylogenies using the Maximum Parsimony (MP) method implemented in MEGA v. 4.0 (Tamura et al., 2007). In the analyses, gaps were treated as missing data. Support for internal nodes was assessed using bootstrap analysis (Felsenstein, 1985) of 1000 replicates with 100 random additions per replicate and holding 10 trees at each step.

\section{Results and Discussion}

Hydrocotyle kollimalayensis S. Karup. \& A. Ali, sp. nov.

(Fig. 1).

Diagnosis: Planta H. sibthorpioides simulans; caulibus filiformis, sparsim pilosis, folis angulatis, supra sparsim pilosis secus nervos villosis, subtus dense villosis vel molliter hirsutis, profunde angulate 5-lobatis, lobis triangulates, crenatis acutis, acuminatisque duplo dentatibus obtusis, pedunculis quam foliis multo brevioribus, umbellis simplicibus globosis 6-12-floris, pedicillis glabris, petalis albis, stylis divaricatis, stylopodio depresso, fructibus ellipsoidus glabratis, costis obscures.

Type: India. Tamil Nadu, Kolli hills, Solakkadu, $78^{\circ} 17^{\prime}-7^{\circ} 27^{\prime}$ E longitude, $11^{\circ} 55^{\prime}-11^{\circ} 21^{\prime} \mathrm{N}$ latitude, 1250 m, 14 Jul 2009, S. Karuppusamy 24375 (Holotype: MH).

Perennial herbs. Stem weak, slender, filiform, silky setaceous, creeping, rooting at nodes. Leaves simple, pale green, sparsely hirsute above and dense below, membranous, base cordate, $1.5-2.0 \mathrm{~cm}$ wide, $1.0-1.5 \mathrm{~cm}$ long, angular, margin shallowly 5-lobed, lobes acute or obscurely triangular, middle lobe larger than the others, crenate, subequal. Petioles slender, $2-4 \mathrm{~cm}$ long, with white reflexed hirsute hairs above. Umbels simple, 6-12 flowered, globose; peduncle 1.0-2.5 $\mathrm{cm}$ long, glabrous, axillary, slender. Flowers sub-sessile or very shortly pedicillate. Petals ovate, white, entire, minute, c. $0.2 \mathrm{~mm}$ long, triangular, acute. Stamens 5, minute, slightly incurved in 
bud; filaments short, c. $0.1 \mathrm{~mm}$ long; anthers bilobed. Ovary minute, ellipsoidal, greenish; style 1, persistent; stylopodium slightly elevated. Fruits ellipsoid, compressed, with obscure dorsal edges, glabrous, 3-ribbed, ribs obscure, subequal, c. $1.2 \mathrm{~mm}$ long and c. $1 \mathrm{~mm}$ wide, glabrous above, minutely granulate at base, pale brown.

Phenology: Flowering and fruiting occurs almost throughout the year.

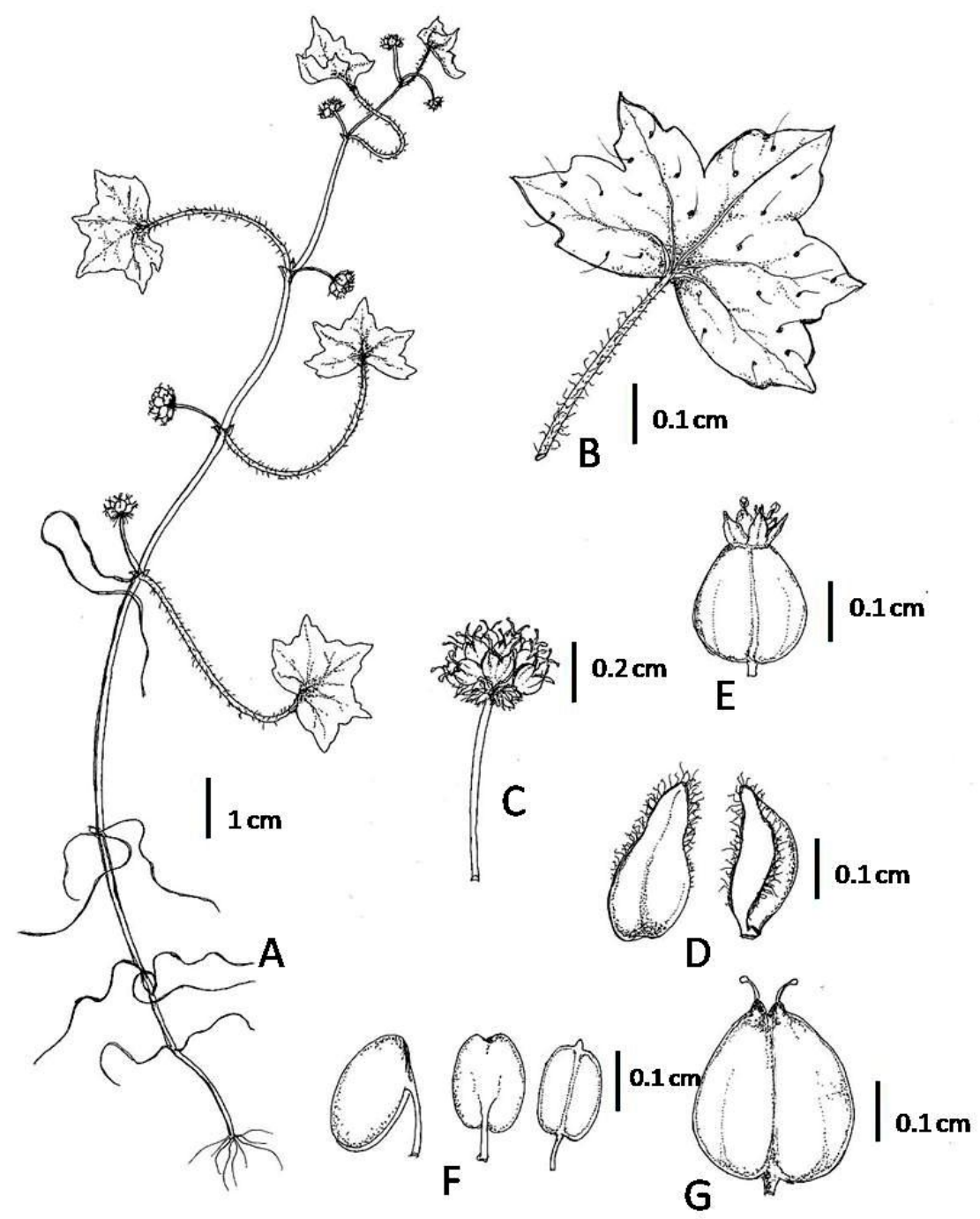

Fig. 1. Hydrocotyle kollimalayensis S. Karup. \& A. Ali, sp. nov. A. Habit; B. Leaf; C. Inflorescence; D. Bracts; E. Flower; F. Anthers; G. Fruit. (Drawn from the holotype.)

Distribution: Hydrocotyle kollimalayensis is known from Solakkadu, near observatory, Kolli hills of Southern Eastern Ghats in Tamil Nadu, India (Fig. 2). It grows in between 1200 to $1350 \mathrm{~m}$ elevation.

Etymology: The new species is named after the type locality Kollimalai, from where we collected the plant populations. 
Conservation status: The new species, according to IUCN Red list category (IUCN, 2012), is considered under 'Endangered' category (EN, criteria B).

Notes: Hydrocotyle kollimalayensis is morphologically similar to $H$. sibthorpioides, however, it differs from the latter by its filiform stem with silky setaceous hairs, more number of flowers per inflorescence, glabrous peduncle and obscure ribs on fruits. A comparative account of $H$. kollimalayensis with its closely related species $H$. sibthorpioides, $H$. conferta and $H$. javanica is presented in Table 1. The morphological characters which are used to delimit the species of Hydrocotyle include habit, stem, leaves, flowers and fruits. However, the genus Hydrocotyle shows much variation in morphological characters, which often creates difficulties in demarcating the taxonomic ranks at or below the species level (Hiroe, 1979). Earlier floristic reports (Gamble, 1935; Matthew, 1983) from Tamil Nadu (India) represented only three species of Hydrocotyle L. i.e. $H$. conferta, $H$. javanica and $H$. sibthorpioides. Hydrocotyle kollimalayensis is allied to $H$. sibthorpioides which can be evidenced from the morphological comparison (Table 1).

Table 1. Comparison of diagnostic morphological characters of Hydrocotyle kollimalayensis sp. nov. with its allied species.

\begin{tabular}{|c|c|c|c|c|}
\hline Characters & H. kollimalayensis & H. sibthorpioides & H. conferta & H. javanica \\
\hline Stem & Filiform & Wiry & Wiry & Wiry \\
\hline Stem hairs & Silky setaceous & Hirsute & Hirsute & Hirsute \\
\hline Leaves & 5-lobed & 5-7-lobed & 7-9-lobed & 7-11-lobed \\
\hline Leaf indumentum & $\begin{array}{l}\text { Sparse hirsute above } \\
\text { and dense below }\end{array}$ & $\begin{array}{l}\text { Hirsute on both } \\
\text { surface }\end{array}$ & $\begin{array}{l}\text { Hirsute on both } \\
\text { surface }\end{array}$ & $\begin{array}{l}\text { Hirsute on both } \\
\text { surface }\end{array}$ \\
\hline Petiole & $2-4 \mathrm{~cm}$ long & $2-3 \mathrm{~cm}$ long & $2-6 \mathrm{~cm}$ long & $5-15 \mathrm{~cm}$ long \\
\hline $\begin{array}{l}\text { No. of flowers per } \\
\text { inflorescence }\end{array}$ & $6-12$ & $3-10$ & $10-20$ & $20-30$ \\
\hline Peduncle & Glabrous & Hirsute & Hirsute & Hirsute \\
\hline Flowers & $0.1 \mathrm{~mm}$ wide & $0.2 \mathrm{~mm}$ wide & $0.3 \mathrm{~mm}$ wide & $0.5 \mathrm{~mm}$ wide \\
\hline Fruits & Ellipsoidal & Ellipsoidal & Suborbicular & Suborbicular \\
\hline Ribs on fruits & 3 , obscure & 3, distinct & 3 , obscure & 5 , distinct \\
\hline
\end{tabular}

\section{Phylogenetic relationship}

The phylogenetic relationship of Hydrocotyle kollimalayensis with its allied species is presented in Figure 3. The combined length of the entire ITS region (ITS1, 5.8S and ITS2) in the species included ranged from 604-625 bp. The length of ITS1 region ranged from 208-230 bp, the $5.8 \mathrm{~S}$ gene was $161 \mathrm{bp}$, and the length of ITS2 region varied from 227-237 bp. In $H$. kollimalayensis, the combined length of the ITS region was 606 bp (the length of ITS1 and ITS2 region was $210 \mathrm{bp}$ and $235 \mathrm{bp}$, respectively). Aligned data matrix has a total number of 656 characters of which 450 characters were constant, 113 characters were variable but parsimonyuninformative, and 99 were parsimony-informative. Insertions and deletions (indels) were necessary to align the sequences. Indels ranged from 1-17 bp. The parsimony analysis of the entire ITS region resulted into 14 Maximum Parsimony Trees (MPTs) with a length of 88 steps, a consistency index (CI) of 0.711, a homoplasy index (HI) of 0.201 , rescaled consistency index (RC) of 0.503 , and a retention index (RI) of 0.727 .

In MPTs, H. kollimalayensis shows proximity (bootstrap support $86 \%$ ) with $H$. conferta and $H$. javanica, and is clearly distinct from $H$. sibthorpioides (Fig. 3). A comparison of nrDNA ITS sequence of $H$. kollimalayensis with the allied species $H$. javanica, $H$. sibthorpioides and $H$. conferta reveals the differences of 25,33 and $42 \mathrm{bp}$, respectively. 


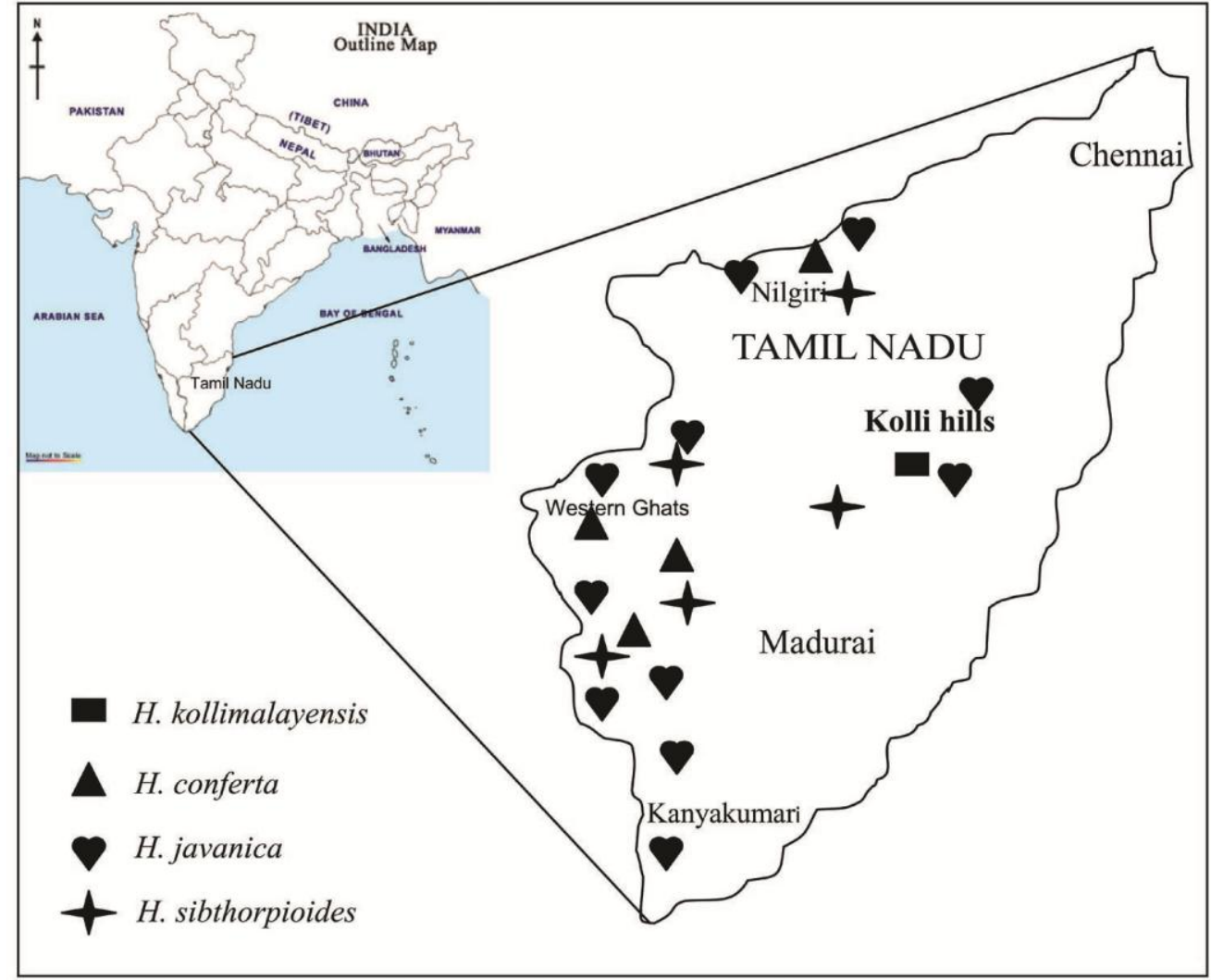

Fig. 2. Distribution map of Hydrocotyle kollimalayensis and its related species in Tamil Nadu, India.

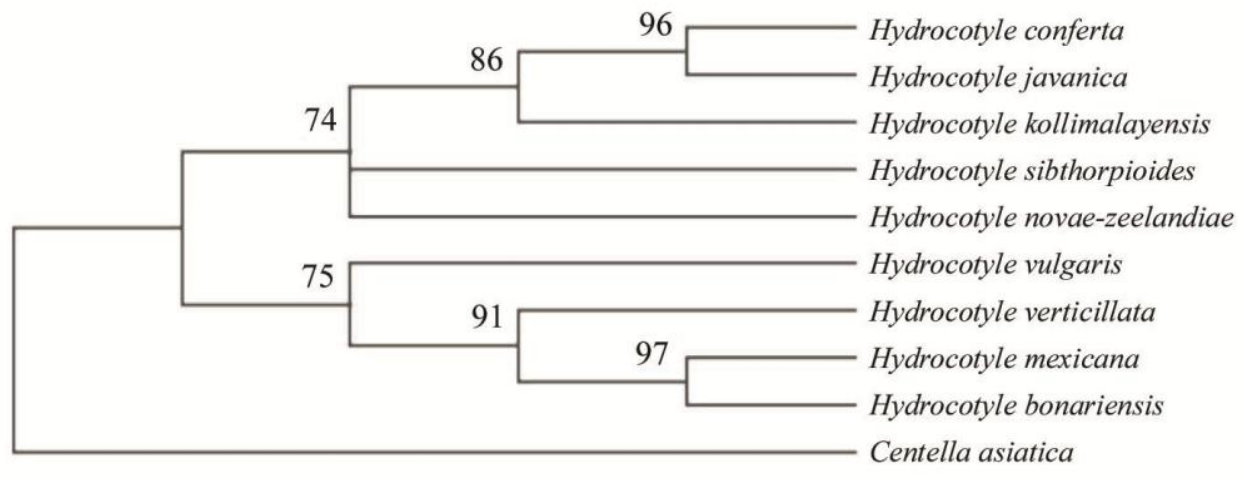

Fig. 3. The bootstrap strict consensus tree of 14 maximally parsimonious trees of Hydrocotyle inferred from ITS sequences of nrDNA data. Numbers above the line indicate bootstrap values in 1000 bootstrap replicates. 


\section{Key to the species of Hydrocotyle L. in Tamil Nadu, India}

Subsequent to the discovery of the new species Hydrocotyle kollimalayensis, the total number of species of Hydrocotyle in Tamil Nadu, India has been increased to four. A key is provided herewith to facilitate easy identification of the taxa.

1. Stem wiry; Leaves orbicular, reniform; peduncle hirsute; flowers

0.2-0.5 mm wide.

2. Umbel solitary on axillary nodes; mericarps compressed; ribs 3 on fruits.

3. Leaves $>1.5 \mathrm{~cm}$ in diameter; peduncle very short or sessile.

3. Leaves $<1.5 \mathrm{~cm}$ in diameter; peduncle c. $1.2 \mathrm{~cm}$ long. $\quad H$. sibthorpioides

2. Umbel clustered on terminal and subterminal nodes; mericarps $H$. javanica slightly compressed; ribs 5 on fruits.

1. Stem filiform; leaves angular, not reniform; peduncle glabrous; flowers H. kollimalayensis c. $0.1 \mathrm{~mm}$ wide.

\section{Acknowledgement}

We are thankful to the curators and staffs of MH, CAL, BSHC, ARUN, ASSAM and DD for providing facility for herbarium and library consultation. Research supported by the King Saud University, Deanship of Scientific Research, College of Science, Research Center.

\section{References}

Choi, K.S. and Park, S. 2012. Molecular phylogenetic studies of Korean Hydrocotyle L. Korean J Plant Res. 25(4): 490-497.

Clarke, C.B. 1879. Hydrocotyle. In: Hooker, J.D., Flora of British India, 2: 667-669. Reeve \& Co., England.

Du, X.C. and Ren, Y. 2010. Hydrocotyle changanensi (Araliaceae), a new species from Shaanxi, China. Ann. Bot. Fenn. 47: 403-407.

Felsenstein, J. 1985. Confidence limits on phylogenies: An approach using the bootstrap. Evolution 39: 783791.

Gamble, J.S. 1935. Hydrocotyle. In: Flora of the Presidency of Madras. Adlard \& Son, London, pp. 555-556.

Hall, T.A. 1999. BioEdit: a user-friendly biological sequence alignment editor and analysis program for Windows 95/98/NT. Nucleic Acids Symp. Ser. 41: 95-98.

Hiroe, M. 1979. Hydrocotyle. In: Umbelliferae of World. Ariake Book Company, Matsuo Biru, Tokyo, Japan, pp. 103-168.

IUCN 2012. IUCN Red List Categories and Criteria: Version 3.1. Second edition. Gland, Switzerland and Cambridge, UK: IUCN. iv + 32 pp.

Karthikeyan, S., Sanjappa, M. and Moorthy, S. 2009. Apiaceae [Umbelliferae]. Flowering plants of India, Dicotyledons. Vol. I (Acanthaceae-Avicenniaceae). Botanical Survey of India, Howrah, India, pp. 98127.

Mathias, M.E. 1936. The genus Hydrocotyle in northern South America. Brittonia 2: 201-237.

Matthew, K.M. 1983. Apiaceae. In: Flora of Tamil Nadu Carnatic, Vol. 1. Rapinet Herbarium, Tiruchirapalli, Tamil Nadu, India, pp. 815-827.

Matthew, K.M. 1996. Apiaceae. In: Flora of Palni hills, Vol. 1. Rapinet Herbarium, Tiruchirapalli, Tamil Nadu, India., pp. 757-765. 
Mukherjee, P.K. and Constance, L. 1993. Umbelliferae (Apiaceae) of India. Oxford \& IBH Pub. Co. Ltd., New Delhi, pp. 279-286.

Pimenov, M.G. and Leonov, M.V. 1993. The Genera of the Umbelliferae: A nomenclature. Royal Botanic Gardens, Kew, pp. 5-161.

Pullaiah, T., Ramamurthy, K.S. and Karuppusamy, S. 2007. Flora of Eastern Ghats, Hill ranges in South India, Vol. 3. Regency Publications, New Delhi, India, pp. 125-127.

Tamura, K., Dudley, J. Nei, M. and Kumar, S. 2007. MEGA 4: Molecular evolutionary genetics analysis (MEGA) software, version 4.0. Mol. Biol. Evol. 24: 1596-1599.

Thompson, J.D., Gibson, T.J., Plewniak, F., Jeanmougin, F. and Higgins, D.G. 1997. The Clustal X windows interface: flexible strategies for multiple sequence alignment aided by quality analysis tools. Nucleic Acids Research 24: 4876-4882.

White, T.J., Bruns, T., Lee, S. and Taylor, J. 1990. Amplification and direct sequencing of fungal ribosomal RNA genes for phylogenetics. In: Innis, M., Gelfand, D., Sninksky, J. and White, T. (Eds), PCR protocols: a guide to method and application. Academic Press, San Diego, California, USA, pp. 315 322.

\section{APPENDIX I}

Ingroup: *H. bonariensis Lam., AF077894. ${ }^{\dagger} H$. conferta Wight, Palni hills, Tamil Nadu, India, S. Karuppusamy $25374(\mathrm{MH})$, GU447310. ${ }^{\dagger}$ H. javanica Clarke, Kolli hills, Tamil Nadu, India, S. Karuppusamy 25147 (MH), U447308. ${ }^{\dagger}$ H. kollimalayensis S. Karup. \& A. Ali sp. nov. Kolli hills, Tamil Nadu, India, S. Karuppusamy $24375(\mathrm{MH})$ GU447311. *H. mexicana Schltdl. \& Cham., AF077893. *H. novae-zeelandiae DC., AF272356. 'H. sibthorpioides Lam. Palni hills, Tamil Nadu, India, S. Karuppusamy $24314(\mathrm{MH})$, GU447309. *H. vulgaris L., AF077895. *H. verticillata Thunb., AY389025. Outgroup: *Centella asiatica (L.) Urban, Jeollanam-do, Korea, K.S. Choi 20090522 (YNUH), JQ247225.

${ }^{\dagger}$ denotes that the sequences were generated in the present study and submitted to GenBank, and

* indicates that the sequences were retrieved from GenBank. 